\title{
ŚLADY POLSKIEJ WYMOWY GWAROWEJ W NAZWACH TERENOWYCH W PAŃSTWOWYM REJESTRZE NAZW GEOGRAFICZNYCH
}

\author{
Ewa Wolnicz-Pawłowska \\ Komisja Nazw Miejscowości i Obiektów Fizjograficznych \\ ORCID: 0000-0002-5957-7854
}

\begin{abstract}
Streszczenie. W artykule wskazano elementy gwarowe w Państwowym Rejestrze Nazw Geograficznych (PRNG), tzn. centralnym, stale aktualizowanym wykazie nazw geograficznych zbieranych do celów administracyjnych. Nazwy te funkcjonują nie tylko w lokalnej społeczności, ale także w szerokim obiegu społecznym, są bowiem obecne - oprócz PRNG - na ogólnodostępnych mapach topograficznych.

Przykładowo wymieniono dziesięć cech gwarowych, zarejestrowanych w materiałach PRNG przeznaczonych do standaryzacji przez Komisję Nazw Miejscowości i Obiektów Fizjograficznych. Po konsultacjach z gminami część nazw obiektów fizjograficznych prawdopodobnie zachowa swoją postać gwarową, aby zbliżyć oficjalne wykazy z lokalną wymową.
\end{abstract}

Slowa klucze: nazwy terenowe, standaryzacja, cechy gwarowe, Państwowy Rejestr Nazw Geograficznych

\section{WSTĘP}

Od kiedy zaczęłam uczestniczyć w życiu naukowym, w różnych wypowiedziach konferencyjnych, dyskusjach medialnych itp. słyszałam głosy na temat rychłego zaniku gwar, wypieranych przez język „ogólny”, rozpowszechniany i promowany w szkole oraz środkach masowego przekazu. Podobne przekonanie stało za licznymi projektami badawczymi krajowymi i ponadnarodowymi (np. atlas gwar Europy, ogólnosłowiański atlas językowy czy karpacki atlas dialektologiczny), mającymi na celu zarejestrowanie istniejących jeszcze gwarowych systemów komunikacji. W Polsce w wielu ośrodkach uniwersyteckich oraz instytutach PAN realizowane były programy zbierania materiałów gwarowych, a następnie opracowywania regionalnych atlasów i słowników. Młodych adeptów nauki zachęcano do udziału w tych programach, które okazały się bardzo atrakcyjne. W konsekwencji działania te dały olbrzymi dorobek polskiej dialektologii i szczegółową wiedzę o systemie gramatycznym, zasobach leksykalnych, gatunkach tekstowych itd. 
Chociaż gwary przez ostatnie półwiecze nie zanikły, to widocznie się zmieniły. Zmieniła się także dialektologia jako nauka, jej narzędzia badawcze, sposoby interpretacji materiału, rozumienie specyfiki komunikacji językowej, nie mówiąc już o nowych możliwościach prezentacji materiału w przekazie elektronicznym. Dialektolodzy sięgają też po nowe źródła materiałowe, jak np. lokalna prasa, dokumenty historyczne czy dzieła literackie. Obiektem badań są również nazwy własne.

W swoim artykule chciałabym wskazać elementy gwarowe w materiale współczesnym, w nazwach funkcjonujących w szerokim obiegu społecznym, mianowicie w centralnym wykazie nazw geograficznych zbieranych do celów administracyjnych. Mowa o Państwowym Rejestrze Nazw Geograficznych (PRNG), czyli „urzędowej, prowadzonej na szczeblu centralnym, referencyjnej bazie danych zawierającej wiarygodne, aktualne i zalecane do oficjalnego stosowania nazwy obiektów geograficznych"1. Materiały PRNG, udostępnione w Internecie, były już wykorzystywane w pracach językoznawczych ${ }^{2}$. Warto poświęcić kilka słów charakterystyce tej bazy danych, aby lepiej ocenić jej zalety i ograniczenia w badaniach językowych.

\section{PRNG JAKO ŹRÓDŁO NAZW OBIEKTÓW FIZJOGRAFICZNYCH}

Państwowy Rejestr Nazw Geograficznych działa w strukturach Głównego Urzędu Geodezji i Kartografii na podstawie rozporządzenia Ministra Rozwoju, Pracy i Technologii ${ }^{3}$. Gromadzenie podobnych baz danych jest współcześnie na świecie zjawiskiem powszechnym. Ich początków szukać trzeba $\mathrm{w}$ powojennych próbach wprowadzenia nowych zasad urządzania i funkcjonowania państw i społeczeństw. „Po drugiej wojnie światowej próby wprowadzenia nowego ładu na świecie i w stosunkach międzynarodowych przybrały formy instytucjonalne, z Organizacją Narodów Zjednoczonych na czele. W tym politycznym projekcie od początku dużą rolę wyznaczono uporządkowaniu nazewnictwa geograficznego. Miało to sprzyjać dokładnemu

\footnotetext{
J. Kacprzak, I. Zieliński, Problematyka standaryzacji i wizualizacji danych Państwowego Rejestru Nazw Geograficznych (PRNG), „Polish Cartographical Review. Suplement w języku polskim" 2017, t. 2, nr 1, s. 87.

2 Por. np. E. Wolnicz-Pawłowska, Z problemów standaryzacji nazw obiektów fizjograficznych Lubelszczyzny. Nowa sytuacja prawna, nowe i stare problemy, [w:] Pogranicza słowiańskie w opisach językoznawczych, red. F. Czyżewski, M. Olejnik, A. Pihan-Kijasowa, Lublin-Włodawa 2015, s. 297-306; M. Koper, Powiat tomaszowski w pejzażu toponimicznym pogranicza polsko-ukraińskiego, Lublin 2019.

Zob. rozporzadzenie Ministra Rozwoju, Pracy i Technologii z dn. 29 stycznia 2021 w sprawie państwowego rejestru nazw geograficznych (Dz.U. z 2021 r., poz. 273) - za geoportal.gov.pl/ dane/panstwowy-rejestr-nazw-geograficznych, dostęp 26.07.2021.
} 
rozpoznaniu przestrzeni działań międzynarodowych, zaś przez wprowadzenie unifikacji nazewnictwa - zapewnić skuteczną komunikację i współpracę w skali globalnej. Postęp techniczny, który się dokonał w XX wieku, przemiany polityczno-społeczne na świecie, a także sama koncepcja Organizacji Narodów Zjednoczonych sprzyjały podjęciu wyzwania. Należy zaznaczyć, że kraje członkowskie, skupione w Organizacji Narodów Zjednoczonych, zobowiązane są do realizacji zadań, wyznaczonych w rezolucjach przyjmowanych na konferencjach ONZ"4. Polska uczestniczyła od początku w tej współpracy, tj. od pierwszej konferencji ONZ poświęconej nazewnictwu geograficznemu 1967 r. Wśród celów, jakie wówczas nakreślono, wymienić trzeba przede wszystkim rozwiązywanie problemów narodowej i ponadnarodowej standaryzacji. Efektem standaryzacji miały być wykazy urzędowych toponimów dla szerokiego rozpowszechnienia form znormalizowanych w skali krajowej i międzynarodowej. Obecnie w krajach zrzeszonych w ONZ powszechne jest zbieranie danych o obiektach geograficznych oraz tworzenie krajowych baz danych, organizowanych według jednolitych założeń.

W PRNG - jeśli chodzi o nazwy obiektów fizjograficznych - do bazy danych wprowadzano przede wszystkim nazwy urzędowe, tj. z wykazów opublikowanych w Monitorze ${ }^{5}$ i Dzienniku Ustaw. Obok tego gromadzono nazewnictwo ze współczesnych map topograficznych, m.in. z map w skali 1:10000 i 1:50000 . Ponadto w ramach aktualizacji danych PRNG, Główny Urząd Geodezji i Kartografii pozyskał w latach 2012-2014 w drodze zamówień publicznych ponad 37 tys. nazw obiektów fizjograficznych z obszaru Polski ${ }^{7}$. W materiałach PRNG nazwy takie oznaczone są w rubryce "Źródło” jako „wywiad terenowy”. Przygotowując materiały dla Państwowego Rejestru, gminy korzystały z różnych, dostępnych im źródeł, niemożliwych do ustalenia dla użytkownika strony Centralnego Ośrodka Dokumentacji Geodezyjnej i Kartograficznej (www.geoportal.gov.pl). Można się tylko domyślać, że nazwy dróg, lasów i ich części pochodzą w tym zbiorze od służb leśnych i drogowych. „W 2017 roku PRNG zawierał 123018 nazw obiektów fizjograficznych o różnym statusie (urzędowe, zestandaryzowane, niestandaryzowane $\mathrm{i}$ in.). Około 60000 tych nazw stanowią nazwy terenowe, takie jak nazwy łąk, pól, lasów i ich części, polan, uroczysk, bagien itp."».

4 E. Wolnicz-Pawłowska, W pięćdziesięciolecie pierwszej „,Konferencji Narodów Zjednoczonych do Ujednolicenia Nazw Geograficznych”, „Polish Cartographical Review. Suplement w języku polskim”, 2017, t. 2, nr 2, s. 222.

5 „Monitor Polski” był oficjalnym organem Rady Ministrów w latach 1946-1950.

$6 \quad$ O zakresie i treści tych map por. P. Kowalski, J. Siwek, Polskie mapy topograficzne do użytku powszechnego - ćwierć wieku sukcesów czy niepowodzeń?, „Polski Przegląd Kartograficzny", 2013, t. 45, nr 4, s. 334-343.

7 J. Kacprzak, I. Zieliński, op. cit., s. 88.

8 Ibidem, s. 90. 
Ze względu na to, że znaczna część zbioru PRNG nie przeszła procesu standaryzacji, od 2014 roku prowadzone są systematyczne prace w Komisji Nazw Miejscowości i Obiektów Fizjograficznych (KNMiOF) nad zaopiniowaniem materiałów, dostarczanych przez PRNG w postaci tabel według poszczególnych województw. Na początku 2020 roku wstępnie zaopiniowanych pozytywnie było ponad 53000 nazw. Część tabel z uwagami Komisji przesyłano do gmin z prośbą o wyjaśnienia. Większość gmin nie wniosła żadnych uwag, inne prosiły o pozostawienie haseł bez zmian, a pewna niewielka część gmin dokonała rzeczowej weryfikacji. Przykładowo w gminie Bełchatów w woj. łódzkim w PRNG występowała nazwa Kaski Ług 'część lasu' (źródło: mapa topograficzna w skali 1: 10 000); Komisja pytała, czy nie jest to pomyłka literowa zamiast Kącki Ług, jednak gmina wyjaśniła, że prawidłowa jest forma Koński Ług. W gminie Bedlno w tymże województwie stwierdzono, że kilka nazw podanych w wykazie, takich jak np. Gawrony 'łąka' (mapa 1:10 000), Kozienie 'pole' (wywiad terenowy) i in., w ogóle w obiegu społecznym nie funkcjonuje. Podobnie gmina Kleszczów nie potwierdziła występowania na swoim terenie nazwy Nokreć 'część lasu' (mapa 1:10 000). Takie uwagi z gmin każą podchodzić z ostrożnością do form zamieszczonych w PRNG, zwłaszcza jeśli wykaz ten jest jedynym źródłem informacji dla badacza językoznawcy. Warto w tym miejscu zauważyć, że dane PRNG nie były uzupełniane na podstawie „Urzędowych nazw miejscowości i obiektów fizjograficznych” (1963-1975, tzw. UN), a porównanie obu tych źródeł ujawnia liczne rozbieżności. Trzeba także zaznaczyć, że wnikliwa analiza map topograficznych wydawanych w XXI wieku do użytku powszechnego, dokonana przez kartografów, pokazała, że tylko część arkuszy map w skali 1:10 000 i 1:50 000 została opracowana według stanu z początku XXI wieku, inne powielano z wcześniejszych wydań z drugiej połowy XX wieku. ${ }^{9}$ Słowem, o ile PRNG jest ogromnie przydatne przy dokładnej lokalizacji obiektów fizjograficznych, o tyle forma językowa nazw niekiedy wymaga weryfikacji, ponieważ zapisy nie są datowane, brakuje także danych o pierwotnym źródle zapisu.

\section{FORMY GWAROWE W NAZWACH OBIEKTÓW FIZJOGRAFICZNYCH W PRNG}

Przeznaczone do standaryzacji wykazy są przygotowywane na posiedzenia KNMiOF przez PRNG według województw. W materiałach tych, jak się okazuje, znalazło się sporo nazw o cechach gwarowych ${ }^{10}$. Pochodzą one zarówno

\footnotetext{
9 Szczegółowe pokrycie obszaru Polski przez arkusze z różnych lat zob. P. Kowalski, J. Siwek, op. cit.

10 Wskazywałam na to w art. E. Wolnicz-Pawłowska, Z problemów standaryzacji nazw obiektów...
} 
z map topograficznych, jak i ze wspomnianych wyżej zamówień publicznych, tj. opracowań z urzędów gminnych z lat 2012-2014. Poniższy wybór materiału ma charakter przeglądowy, nie obejmuje wszystkich cech gwarowych ani wszystkich nazw z takimi cechami. Zajęłam się tylko gwarami polskimi, pomijając formy pochodzące z języków mniejszościowych. Chodziło mi o pokazanie, że w lokalnych społecznościach funkcjonuje sporo form gwarowych, które za sprawą działań administracyjnych państwa przedostają się do obiegu ogólnokrajowego i do oficjalnego zasobu polskich geonimów.

Przykłady nazw obiektów fizjograficznych podaję w kolejności alfabetycznej ze wskazaniem rodzaju obiektu oraz lokalizacji w gminie i województwie, a także z określeniem rodzaju źródła (mapa lub wywiad terenowy).

1. Mazurzenie jest jedną z najbardziej rozpowszechnionych cech gwarowych w materiałach PRNG. Zapisy z tą cechą wystąpiły w wielu województwach, m.in. mazowieckim, łódzkim, lubelskim, małopolskim, śląskim i podlaskim. W zasadzie od wielu lat $\mathrm{w}$ procesie standaryzacji mazurzenie z nazw usuwano, zastępując formami ogólnopolskimi. Tak postępowano, np. redagując zeszyty UN, pisał również o tym wprost Kazimierz Rymut (1989), wieloletni członek i przewodniczący KNMiOF. Od wieków mazurzenie uchodziło za cechę poniżej normy poprawnościowej. W konsekwencji działań standaryzacyjnych $\mathrm{w}$ zasobie polskich nazw geograficznych znajduje się niewiele form z mazurzeniem, por. np. nazwy miejscowości Międzyrzec (zamiast Międzyrzecz), Prace (zamiast Pracze).

Materiał przykładowy

Babcyn Grób ‘część lasu’ w gm. Alwernia, Młp, WT; Bajcyna Droga ‘droga' w gm. Borowie, Maz, WT; Bujac 'łąka' w gm. Bieruń, Ś, M10; Byce 'łąka' w gm. Łyse, Maz, WT (dwa obiekty), tamże Za Byce 'łąka' WT; Brzezki 'jar' w gm. Mszana Dolna, Młp, WT; Chwilcyno 'droga' w gm. Pajęczno, Ł, WT; Ciesacin 'bagno' w gm. Cyców, L, M10; Cłapiec 'łąka' w gm. Galewice, Ł, M10; Dorsowa Góra 'wzgórze' w gm. Kadzidło, Maz, WT; Drozyna 'droga' w gm. Drzewica, Ł, WT; Głowcyn 'droga' w gm. Aleksandrów, Ł, WT; Godos 'pola' w gm. Kałuszyn, Maz, M10; Górcane 'część lasu' w gm. Brańszczyk, Maz, M10 (por. tamże Górczana 'droga' WT); Górki Mierzączkie 'wzgórza' w gm. Dłutów, Ł, M10 (forma hiperpoprawna, ib. wieś Mierzaczka); Grabcyny 'łąki' w gm. Gielniów, Maz, M10; Gronicek 'polana' w gm. Szczyrk, Ś, M10; Kacałok 'część lasu' w gm. Czosnów, Maz, M10; Karce 'część lasu' w gm. Nowe Piekuty, Pod, M10; Karcówki 'łąki' w gm. Grabica, Ł, M10; Kołacki 'łąki' w gm. Brzesko, Młp, M10 (tamże nazwisko Kołaczek); Korcun 'łąka' w gm. Łowicz, Ł, M10; Korcunki ‘część lasu’ w gm. Kruszyna, Ś, WT; Krucówki 'łąki' w gm. Dzwola, L, M10; Krucyce 'łąka' w gm. Wola Krzysztoporska, Ł, WT (por. Kruczyce - kilka innych obiektów w tym województwie); Krzaki Kopcyne 'las' w gm. Nowa Brzeźnica, Ł, WT (gmina zweryfikowała 
nazwę jako Krzaki Kopczyne); Kucnerka 'część lasu' w gm. Kluki, Ł, M10; Kurcunki 'las' w gm. Adamów, L, WT (dwa obiekty); Łuski pl 'łąka' w gm. Gniewoszów, Maz, M10, tamże Euzek 'łąka' M10 i Łuski ‘część lasu’ w gm. Tomaszów Maz., Ł, M10; Makocówka 'pole' w gm. Biecz, Młp, WT; Marscota 'pole' w gm. Opoczno, Ł, M10; Macyska 'ląka' w gm. Rozprza, Ł, WT; Mysadla 'las' w gm. Mszczonów, Maz, M10; Mysadle 'torfowisko' w gm. Kowiesy, Ł, WT; Olsówka 'pole' w gm. Mstów, Ś, M10; Pod Pscelnikiem 'pole' w gm. Przedbórz, Ł, WT; Pod Subienice 'pola' w gm. Łubnice, Ł, M10; Przecy 'pole' w gm. Sokoły, Pod, M10; Przyce 'pola' w gm. Czerwin, Maz, M10; Przyłuski 'las' w gm. Sadkowice, Ł, WT (podany przez gminę dopełniacz: Przylusków sugeruje, że motywacja jest od ap. tużek, a nie tuska, por. też wyżej Łuski); Puzarnica 'część lasu' w gm. Nowe Piekuty, Pod, M10; Rososa 'część lasu' w gm. Siemkowice, Ł, M10; Rozny 'pola’ w gm. Baranów, L, WT; Ryca 'droga' w gm. Kłoczew, L, WT; Scota 'pole' w gm. Gielniów, Maz, M10; Sepce 'łąka' w gm. Ostrówek, Ł, M10 (w UN: Szepcze); Smyca 'część lasu' w gm. Kruszyna, Ś, WT; Spice 'część lasu' w gm. Łubnice, Ł, M10; Spisak 'dolina' w gm. Grybów, Młp, WT; Śmierdzącka 'łąka' w gm. Janów Lub., M10 (ib. rzeka Śmierdziączka) i ‘bagno’ w gm. Biłgoraj, L, M10; Świerc część lasu' w gm. Czastary, Ł, WT (w UN: Świercz); Świercyń 'część lasu' w gm. Babice, Młp, WT; Świrce 'część lasu' w gm. Annopol, L, WT; Uzak 'pole' w gm. Biała, Ł, M10; Uzok 'łąka' w gm. Galewice, Ł, M10 (por. też Korczów Uzok 'część lasu' w gm. Garbatka-Letnisko, Maz, WT - mamy tu w pierwszym wyrazie formę bez mazurzenia, a w drugim z tą cecha); $W$ Uboce 'zbocze' w gm. Muszyna, Młp, WT (tamże Ubocze 'zbocze' WT); Wąsos 'łąka' w gm. Boguty-Pianki, Maz, M10 i 'las' w gm. Nowe Piekuty, Pod, M10; Wesmuskas 'część lasu' w gm. Drzewica, Ł, WT (forma zniekształcona, zapewne od wyrażenia we smużkach); Wycierac 'przełęcz' w gm. Pcim, Młp, WT; Wzary 'część lasu’ w gm. Kamienica, Młp, M10; Zajęce 'łąka' w gm. Sokolniki, Ł, M10; Zamtuce ‘część lasu’ w gm. Dębowa Kłoda, L, M10; Zuki 'część lasu’ w gm. Lubowidz, Maz, WT.

2. Formy z podwyższoną artykulacją samogłosek ( $a$ do $o$; $e$ do $i, y ; o$ do $u$; $o$ nosowe oraz połączenia on, om do nosowego $u$, zapisywanego jako un, um). Podwyższona artykulacja samogłosek (różnego pochodzenia) nie jest tak silnie odrzucana pod względem poprawnościowym, jak mazurzenie. Uznaje się ją za cechę regionalną i często zachowuje w nazwach urzędowych, por. np. nazwy miejscowości Żory, Dąbrówno czy nazwę góry Klimczok. Pozostawienie tej cechy nie dotyczy jednak - ze względu na fleksję - form przymiotnika rodzaju żeńskiego (np. Bąkowo, Czarnot) i rzeczowników żeńskich na -a (Amalio).

Materiał przykładowy - $o$ (w zapisach też $o f$ ) zamiast ogólnego $a$

Amalio 'pole' w gm. Leśnica, O, M10; Bagna pod Olsokiem 'bagno' w gm. Nowa Brzeźnica, Ł, WT (gmina zweryfikowała nazwę jako Bagna nad 
Olszakiem); Bąkowo (dopełniacz Bąkowej) 'część lasu’ w gm. Radłów, O, WT; Chrzonek 'polana' w gm. Czarnia, Maz, WT; Ciosny 'część lasu' w gm. Maciejowice, Maz, WT; Czarnot 'droga' w gm. Krapkowice, O, WT; Ćpoczki 'pole' w gm. Jastrzębia, Maz, M10; Dolina Krowioka 'dolina' w gm. Leśnica, O, WT; Droga nad Krótkimi Dziołami 'droga' w gm. Nowa Brzeźnica, Ł, WT; Dworskie Chojoki 'część lasu' w gm. Kozienice, Maz, WT; Dzioł 'wąwóz' w gm. Niedźwiedź, Młp, WT; Dziołki 'pole' w gm. Ciepielów, Maz, M10 (tamże Dziatki inny obiekt); Glinczory 'pole' w gm. Koronowo, K-P, WT; Głambokot 'droga' w gm. Krapkowice, O, WT (tamże Przy Głambokiej Drodze 'pole' WT); Gojek ‘część lasu’ w gm. Gielniów, Maz, WT; Kapuśnioki 'łąki’ w gm. Świekatowo, K-P, M10; Kopocz 'część lasu' w gm. Drzewica, Ł, M10; Lesionki 'część lasu’ w gm. Włocławek, K-P, M10; Losek 'łąka’ w gm. Magnuszew, Maz, WT, 'wąwóz' w gm. Niedźwiada, L, WT, 'łąka' w gm. Opoczno, Ł, M10; Loski ‘część lasu' w gm. Opoczno, Ł, WT, ‘bagno’ w gm. Strzelce Opolskie, O, WT; Macherlok ‘część lasu' w gm. Wilkowice, Ś, M10; Mechołcz 'ląki' w gm. Zawadzkie, O, M10; Niskie Dziołki 'las' w gm. Nowa Brzeźnica, Ł, WT; Nort 'część lasu' w gm. Górzno, Maz, WT; Nortowy Rów 'parów' w gm. Inowłódz (ib. n. wsi Narty), Ł, M10; Od Bodzonki 'droga' w gm. Długosiodło, Maz, WT; Pisorka 'łąka' w gm. Magnuszew, Maz, M10; Pniokowata 'część lasu, dawniej polana' w gm. Niedźwiedź, Młp, WT; Pod Lipionkami ‘bagno' w gm. Ujazd, Ł, WT; Psiorz 'część lasu' w gm. Dzwola, L, WT; Szlumoki 'las' w gm. Cisek, O, M10; Ślamok 'bagno' w gm. Włoclawek, K-P, M10; Śmierdzonka 'część lasu' w gm. Garbatka-Letnisko, Maz, WT; Świerczok 'droga' w gm. Opole, O, WT; Trzemeszonka 'część lasu' w gm. Rogowo, K-P, M10; Wilczok 'część lasu' w gm. Bestwina, Ś, WT (tamże Wilczak 'wąwóz' M10); Zotpucie 'droga' w gm. Krapkowice, O, WT; Żory 'część lasu' w gm. Olesno, O, WT i 'łąka' w gm. Zawadzkie, O, M10; Żdżory 'część lasu' w gm. Modliborzyce, L, M10.

Materiał przykładowy $-i, y$ zamiast ogólnego $e$

Bida 'część lasu' w gm. Lubochnia, Ł, M10; Droga na Bidę 'droga' w gm. Garbów, L, WT; Bil 'torfowisko' w gm. Kamionka, L, WT ${ }^{11}$; Bile 'polana' w gm. Gostynin, Maz, WT; Bilnik 'ląka' w gm. Zapolice, Ł, M10; Brzyzie w gm. Janów, O; Ścisłe Brzyzki 'część lasu' w gm. Niedźwiedź, Młp, WT; Ćwirtnie 'łąka' w gm. Kazimierz Dolny, L, WT; Dosijki 'część lasu' w gm. Drzewica, Ł, WT; Dziszki 'część lasu’ w gm. Brzeziny, Ł, WT; Dziwcza Góra 'wzgórze' w gm. Strzelno, K-P, WT oraz w gm. Warta, Ł, M10; Pinki 'część lasu’ w gm. Dłutów, Ł, M50 i 'pole’ w gm. Gomunice, Ł, M10; Pirzak ‘wzgó-

11 Nie każdą formę typu Bil, Bile można interpretować jako gwarową zamiast Biel, Biele. Gmina Skierniewice nadesłała wyjaśnienie, że nazwa lasu Bila pochodzi od nazwiska Stanisława Bila i jego syna Jana Bila (czyli jest to nazwa pamiątkowa: Las Bila). Pierwszy z nich był gajowym lasów miejskich przed II wojną światową, drugi opiekował się lasem po wojnie. 
rze' w gm. Złoczew, Ł, M10; Podlisowa 'droga' od n. wsi Podlesie, Maz; Rysztówka 'łąka' w gm. Rejowiec, L, M10; Rzyczki 'łąka' w gm. Iłża, Maz, M10; Rzyczysko 'wąwóz' w gm. Modliborzyce, L, WT; Stare Rzyczysko 'obniżenie, dawniej starorzecze' w gm. Sieradz, Ł, M50; Rzyki 'część lasu' w gm. Rokiciny, Ł, M10; Rzykietka 'łąka' w gm. Ujazd, Ł, M10 (UN: Rzekietka); Siekirze 'łąka' w gm. Janiec, Maz, M10; Stygna 'łąka' w gm. Borkowice, Maz, M10 (w UN w ts. powiecie Ściegna i Stegny); Świrce ‘część lasu' w gm. Annopol, L, WT; Wisiótka 'uroczysko’ w gm. Glinojeck, Maz, WT.

Materiał przykładowy $-u$, ó zamiast ogólnego $o$ oraz un, um, uń zamiast a, on, om, oń

Bubry 'las' i 'łąka' w gm. Leoncin, Maz, WT; Droga Jeziórkowska 'droga' w gm. Glinojeck, Maz, WT; Droga na Łunki 'droga' w gm. Krapkowice, O, WT; Gróbek 'część lasu’ w gm. Murów, O, M10; Grundy 'łąka' w gm. Murów, O, M10; Jeziórki 'pole’ w gm. Gogolin, O, M10, 'pola' w gm. Zadzim, Ł, M10, M50, 'pola' w gm. Janów Podlaski, L, M10; Jeziórko 'bagno' w gm. Jastrzębia, Maz, WT, 'część lasu’ w gm. Babice, Młp, M10, ‘bagno’ w gm. Lipno, K-P, M10, też Łąki na Jeziórku 'ląka' w gm. Chrostkowo, K-P, WT, por. Wieziurek 'część lasu' w gm. Białaczów, Ł; Kłudzie 'łąka' w gm. Drzewica, Ł, M10; Kumorze 'góra' w gm. Chełmiec, Młp, WT; Kumpie 'łąki' w gm. Ryki, L, WT; Piskórz 'las' w gm. Dębe Wielkie, Maz, WT; Ptusy 'pola' w gm. Radzyń, L, WT; Puborowie 'pole' w gm. Gielniów, Maz, WT; Pugielniów 'pole' w gm. Gielniów, Maz, WT; Pużarnica 'pole' w gm. Mordy, Maz, M10; Roguźnie 'pole' w gm. Poświętne, Ł, M10; Rujszcze 'łąki' w gm. Łochów, Maz, M10; Rulki 'pole' w gm. Kołbiel, Maz, M10; Rulne ‘ łąki' w gm. Łochów, Maz, M10; Spióch 'pole' w gm. Modliborzyce, L, M10; Tabórki 'łąka' w gm. Kołbiel, Maz, M10; Woduńca 'wąwóz' w gm. Dzierzkowice, L, M10; Zdrójki ‘łąka' w gm. Warlubie (//Zdrojki), K-P, M10; Żydówiec ‘część lasu’ w gm. Glinojeck, Maz, WT.

Inne cechy gwarowe nie mają w PRNG tak bogatej reprezentacji. Ocena poprawnościowa i decyzje Komisji są w stosunku do nich różne, np. protezy i przestawki na ogół nie są akceptowane, natomiast brak przegłosu i przejście $j a-, r a-\mathrm{w} j e-, r e-z w y k l e \mathrm{w}$ nazwach urzędowych pozostają, jako świadectwo dawnych procesów fonetycznych.

\section{Proteza $H$ -}

Haleja 'droga' w gm. Walce, O, WT; Handrysówka 'polana' w gm. Mszana Dolna, Młp, M10; Hondraski 'polana' w gm. Szczyrk, Ś, WT; Hulica 'droga’ w gm. Krapkowice, O, WT.

4. Labializacja $u$. Zanik nagłosowego $t$ - przed $-u$-. Zanik - $t$ - w grupie $\operatorname{ch} t(o)-$

Łucinki 'część lasu' w gm. Dobroń, Ł, M10; Łukazy 'pole' w gm. Łosice, Maz, M10; Łukaźne 'pole' w gm. Annopol, L, M10; Łukaźniki ‘droga' w gm. Adamów, L, WT. 
Uciowo 'łąka' w gm. Hanna, L, M10; Ug 'łąka' w gm. Łubniany, O, WT; Uzak 'pole' w gm. Biała, Ł, M10; Korczów Uzok 'część lasu' w gm. Garbatka-Letnisko, Maz, WT; Użyk 'część lasu' w gm. Puławy, L, WT;

Chobska Droga 'droga' w gm. Zębowice, O, M10; Chopio Gowa (forma oboczna wobec hasłowej Chtopia Głowa) 'część lasu' w gm. Dobrodzień, O, WT; Chopski Las 'las' w gm. Gidle, Ł, WT (gmina zweryfikowała nazwę jako Chtopski Las).

\section{Brak przegłosu}

Droga Wietraczna 'droga' w gm. Stasiny, L, WT; Góra Pietrowa 'wzgórze' w gm. Kazimierz Dolny, L, M10; Kociet 'łąka' w gm. Osie, K-P, WT; Kociełek 'zagłębienie' w gm. Wieluń, Ł, WT oraz 'zagłębienie' w gm. Nowodwór, L, WT; Pierunka 'las' w gm. Puławy, L, WT.

\section{Nagłosowe je-, re- zamiast ja-, $r a$ -}

Jegle (// Jagle) ' 'ąki' w gm. Sadowne, Maz, M10, tamże Droga Jeglowska WT; Reczki 'łąka' w gm. Lutomiersk, Ł, M10; Redlów 'pole' w gm. Widawa, Ł, M50; Rekowska Droga ‘droga' w gm. Ciepielów, Maz, WT; Rekowy 'łąka' w gm. Dobroń, Ł, WT; Rekówka ‘część lasu’ w gm. Górzno, K-P, M10 (// Rękówka!).

7. Przestawka w grupie spółgłoskowej

Wersiednia 'uroczysko' (pole i łąka) w gm. Borkowice, Maz, M10 (tamże nazwy Średni, Średnie).

8. Podwojone $-n-\mathrm{w}$ formach przymiotnikowych

Glinianna Góra ‘wzgórze’ w gminach Gostycyn, Kęsowo, Tuchola, K-P, WT; Przyrówczanne Pole 'pole' w gm. Gostycyn, K-P, WT (tamże wieś Przyrówka)

9. Wymowa ke-zamiast kie-

Kerkut 'część lasu' (dawniej cmentarz żydowski), gm. Kołbiel, Maz, M10

10. Brak -e-ruchomego

Droga do Piask 'droga' w gm. Brochów, Maz, WT; Kierzk 'część lasu' w gm. Miedźna, Maz, M10; Losk 'pole' gm. Sieradz, Ł, M10.

\section{UWAGI KOŃCOWE}

W wykazach PRNG dialektyzmy stanowią znikomą mniejszość, jednak z uwagi na obszerność zbioru (ponad 120 tysięcy jednostek) - nawet ten niewielki procent jest godny uwagi językoznawcy, zwłaszcza że poświadczone 
są różne cechy gwarowe, niekiedy rzadkie i o ograniczonym zasięgu. Źródłem zapisów były zarówno ogólnodostępne mapy topograficzne, wydawane przez Głównego Geodetę Kraju, jak i dokumentacja lokalnych urzędów i służb. Przedstawione powyżej przykłady z pewnością zasługują na opis bardziej szczegółowy i porównanie ich z warstwą apelatywną.

PRNG jest wykazem aktualnych nazw używanych w powszechnym obie$\mathrm{gu}$, a nie słownikiem etymologicznym. Rozporządzenie, na podstawie którego PRNG działa, nakłada obowiązek stałej aktualizacji, np. po wprowadzeniu zmian przez $\mathrm{KNMiOF}^{12}$. Dialektyzmy, które są w wykazie dostępne dziś, za jakiś czas mogą zatem z listy zniknąć. Część $\mathrm{z}$ nich pozostanie na mapach, natomiast te, które są sygnowane jako „wywiad terenowy”, będą trudne do odnalezienia.

KMNiOF zgodnie $\mathrm{z}$ zasadami standaryzacji ${ }^{13}$ i dotychczasową tradycją dąży do sporządzania wykazów urzędowych w postaci ogólnopolskiej. Zdarza się, że gmina odrzuca sugestię KNMiOF, aby usunąć cechę gwarową, ponieważ chce utrzymać osobliwość, odrębność swojej gwary, którą uważa za wartość (obserwujemy to zwłaszcza na Śląsku). Nie można także wykluczyć, że dana cecha gwarowa została utrwalona w nazwie przez osobę nierozumiejącą znaczenia podstawy motywującej (np. kartografa), ponieważ apelatyw wyszedł z powszechnego użycia, np. nart, radło, kierz.

Ze względu na obowiązujące procedury proces standaryzacji nazw obiektów fizjograficznych w Polsce potrwa jeszcze kilka lat. Z pewnością część urzędowych nazw obiektów fizjograficznych zachowa swoją postać gwarową, podobnie jak urzędowe nazwy miejscowości, aby podkreślić specyfikę regionu i zbliżyć oficjalne wykazy z lokalną wymową.

\section{WYKAZ SKRÓTÓW}

$\begin{array}{ll}\text { gm. } & \text { gmina } \\ \text { KNMiOF } & - \text { Komisja Nazw Miejscowości i Obiektów Fizjograficznych } \\ \text { K-P } & - \text { woj. kujawsko-pomorskie } \\ \text { L } & - \text { woj. lubelskie } \\ \text { Ł } & - \text { woj. tódzkie } \\ \text { M10 } & - \text { mapy topograficzne w skali 1:10 } 000 \text { wydawane przez Główne- } \\ & \text { go Geodetę Kraju w latach } 80 . \text { XX wieku }\end{array}$

12 Zmiany takie są zawsze poprzedzone konsultacjami w gminie, por. wyżej uwagi gmin podane przy materiale przykładowym.

13 Zob. E. Wolnicz-Pawłowska, Podstawowe zasady standaryzacji nazw obiektów fizjograficznych $w$ Polsce. Cz. I, „Onomastica” 2019, LXIII, s. 115-125; eadem, Podstawowe zasady standaryzacji nazw obiektów fizjograficznych w Polsce. Cz. II, „Onomastica” 2020, LXIV, s. 41-52. 


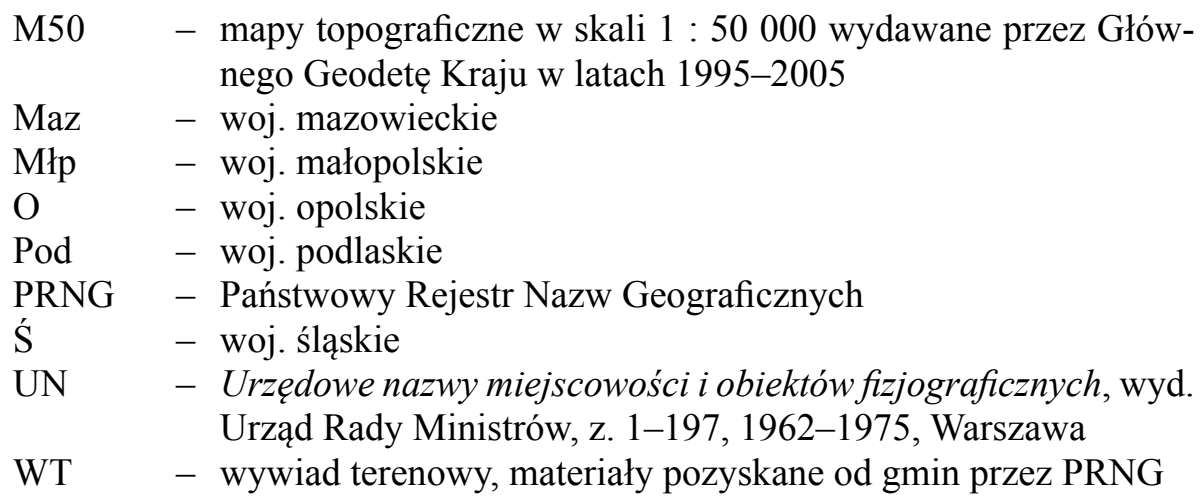

\section{BIBLIOGRAFIA}

Kacprzak Justyna, Zieliński Jerzy. 2017. Problematyka standaryzacji $i$ wizualizacji danych Państwowego Rejestru Nazw Geograficznych (PRNG). „Polish Cartographical Review. Suplement w języku polskim" t. 2, nr 1: 85-92.

Koper Mariusz. 2019, Powiat tomaszowski w pejzażu toponimicznym pogranicza polsko-ukraińskiego. Lublin: Wydawnictwo KUL.

Kowalski Paweł, Siwek Jerzy. 2013. Polskie mapy topograficzne do użytku powszechnego - ćwierć wieku sukcesów czy niepowodzeń?. „Polski Przegląd Kartograficzny” t. 45, nr 4: 334-343.

Rymut Kazimierz. 1989. W sprawie zasad ustalania nazw geograficznych, W: Aktuálne úlohy onomastiky z hl'adiska jazykovej politiky a jazykovej kultury, Zbornik príspievkov z 2. československej onomastickej konferencie (6.-8. Maja 1987 v Smoleniciach). Red. Majtán M. Bratislava: Jazykovedný ústav L'udovita Štúra Slovenskej akademie vied: $36-42$.

Urzędowe nazwy miejscowości i obiektów fizjograficznych, wyd. Urząd Rady Ministrów, z. 1-197. Warszawa 1962-1975.

Wolnicz-Pawłowska Ewa. 2015. Z problemów standaryzacji nazw obiektów fizjograficznych Lubelszczyzny. Nowa sytuacja prawna, nowe i stare problemy. W: Pogranicza słowiańskie w opisach językoznawczych. Red. F. Czyżewski, M. Olejnik, A. Pihan-Kijasowa. Lublin-Włodawa: 297-306.

Wolnicz-Pawłowska Ewa. 2017. W pięćdziesięciolecie pierwszej „,Konferencji Narodów Zjednoczonych do Ujednolicenia Nazw Geograficznych”. „Polish Cartographical Review. Suplement w języku polskim"t. 2, nr 2: 219-225.

Wolnicz-Pawłowska Ewa. 2019. Podstawowe zasady standaryzacji nazw obiektów fizjograficznych w Polsce. Cz. I. „Onomastica” 63: 115-125.

Wolnicz-Pawłowska Ewa. Podstawowe zasady standaryzacji nazw obiektów fizjograficznych w Polsce. Cz. II, „Onomastica” 2020, LXIV, s. 41-52. 


\section{TRACES OF THE POLISH DIALECTAL PRONUNCIATION OF NAMES OF UNINHABITED GEOGRAPHICAL FEATURES INCLUDED IN THE NATIONAL REGISTER OF GEOGRAPHICAL NAMES}

Summary. The paper indicates dialectal elements present in the National Register of Geographical Names (Państwowy Rejestr Nazw Geograficznych), i.e. the central and constantly updated list of geographical names collected for administrative purposes. The names are used not only within local communities but in a wide social circulation as well: besides the National Register they are present on commonly available topographic maps.

The paper provides an illustrative selection of ten dialectal features present in the names included in the National Register and now meant to be standardized by the Commission on Names of Localities and Physiographic Objects. After consultation with local community authorities some of the names which are to be standardized will probably retain their dialectal properties. This is meant to make official name lists closer to the local pronunciation.

Key words: names of uninhabited geographical features, standardization, dialectal features, National Register of Geographical Names

\section{СЛІДИ ПОЛЬСЬКОЇ ДІАЛЕКТНОЇ ВИМОВИ В МІКРОТОПОНІМАХ У ДЕРЖАВНО- МУ РЕЄСТРІ ГЕОГРАФІЧНИХ НАЗВ}

Анотація. У статті вказано діалектні елементи в Державному реєстрі географічних назв (ДРГН), т. зв. центральному, постійно актуалізованому списку географічних назв, що збиралися для держадміністрації. Назви функціонують не тільки серед місцевого населення, але також у ширшому суспільному обігу, оскільки вони містяться, крім ДРГН, також на загальнодоступних топографічних картах.

Як приклад нараховано десять діалектних рис у матеріалах ДРГН, призначених для стандаризації Комісією населених пунктів та фізіографічних об'єктів. Після консультацій з органами місцевого самоврядування частина фізіографічних об'єктів, імовірно, збереже свою діалектну форму, щоб наблизити офіційні списки до локальної вимови.

Ключові слова: мікротопоніми, стандаризація, діалектні риси, Державний реєстр географічних назв 